\title{
A NEEDS ANALYSIS ON STAKEHOLDERS AND ELT STUDENTS TO DEVELOP ENGLISH FOR TOURISM COURSE MATERIAL
}

\author{
Eka Fajar Rahmani ${ }^{\bowtie}$, Iwan Supardi ${ }^{2}$ \\ 1.2Program Studi Pendidikan Bahasa Inggris, Fakultas Keguruan dan Ilmu Pendidikan, \\ Universitas Tanjungpura, Jl. Prof. Dr. H. Hadari Nawawi, 78124. \\ ๑e-mail :ekasastria10@fkip.untan.ac.id
}

\begin{abstract}
This study investigates the needs of tourism stakeholders and students of the English Education Department to develop the English for Tourism (EFT) course material. The participants were ten hotel managers, five travel agents, and 86 second-semester students of the English Education Department. This descriptive quantitative study employed a questionnaire as the primary tool to gather the data adapted from Puspitasari (2018) and Ratmanida et al. (2020). The data then were analyzed using the formula of percentage and mean range table to determine the level of needs from the responses. The results indicated that the stakeholders and students agreed that speaking (100\%) and writing (90\%) were the most needed English skills to acquire. Then, in terms of the EFT topics, the participants responded to the topics that were relevant with their needs or fields. However, specifically, they seemed to have the same opinions and needs for the hotelier topics and some relevant expressions. In short, the results are expected to be beneficial for the EFT course designers to design suitable, directed, and valuable materials for students to help them be skillful and knowledgeable in the tourism industry.
\end{abstract}

Keywords: needs analysis, stakeholders, ELT students, English for Tourism, course materials

\section{Introduction}

Research on needs analysis have been considered important for ESP studies. The needs analysis is an initial stage to develop appropriate ESP materials. Needs analysis is generally defined as the action or process of gathering specific information of students to identify what specific language and skills the group of language learners will need (Basturkmen, 2010). It covers the whole information of what field the learners will practice in the future (Lee, 2016). Flowerdew (2013) explained that needs analysis is actually the technique for collecting and assessing information relevant to course design which covers the how and what of a course, and it is a continuous process of establishing the effectiveness of a course. If needs are precise, the learning aims can be expressed more quickly, and the language course can become motivating. By perceiving students' requirements, the teachers or course designers will be easier in selecting suitable learning materials, techniques, activities, and even assessments (Yundayani, 2018) because considerations and adjustments to the needs have been made.

Comprehensively, needs analysis is a demand that has become a necessary and vital stage of course design for ESP courses since the students' needs are the principal or the core of the course development (Lee, 2016). The language and skills delivered in ESP areas are identified and considered concerning the present state of knowledge of learners, their perceptions of their needs, and practical possibilities and constraints of the teaching context (Basturkmen, 2010). The learners will use those skills right away in their profession or vocational workplaces after finishing their studies. In addition, it is also essential to notice that the critical features of an ESP course are that the content and aims of the courses are oriented to the specific needs of the learners (Songhori, 2008). It involves the learners' willingness, demands, hopes, motivation, and obligations (Kardijan \& Emzir, 2017). Considering its importance needs analysis in ESP courses must be 
conducted beforehand to develop a more relevant and specific course syllabus to help students master and succeed in their study excellently.

There are four components of needs analysis: target situation analysis, learning situation analysis, present situation analysis, and means analysis (Rahman, 2015). Similarly, Basturkmen (2010) suggested two other components: learner factor analysis and discourse analysis. These phases are requirements for conducting the needs analysis because they determine all the needed information. In detail, focusing on the target need analysis (TSA), according to Dudley-Evans as cited in Kardijan and Emzir (2017), TSA concerns the learners' future roles and linguistic skills, and knowledge they need to perform competently in their disciplines. The goal is to gather information about what the learners have to do to acquire the target language (Paltridge \& Starfield, 2013). TSA includes identifying tasks and activities, learners' skills in using English, and what learners should ideally know and do (Basturkmen, 2010). Another component is learning situation analysis (LSA). Rahman (2015) explained that LSA refers to subjective, felt, and process-oriented needs. Quoted by him, Dudley-Evans \& St. John stated that LSA is an effective way of learning the skills and language, referring to why learners want to learn. This component has similarities with the learner factor analysis suggested by Basturkmen (2010) in terms of the identification of the learners' subjectivity in learning, such as their motivation, how they want to learn, and their perceptions of their own needs. The other component is present situation analysis (PSA?) which tries to ensure what the students would obtain at the beginning of the language course, focusing on their strengths and weaknesses (Robinson cited in Rahman, 2015). Yundayani (2018) emphasized that PSA is considered the umbrella that embraces students' lack of language proficiency. There are three primary sources of information in the present situation analysis: the students, the language-teaching establishment, and the user-institution such as the students' workplaces (Rahman, 2015). By doing PSA, the course designer would obtain richer information or data from the students, especially their current skills and language use (Yundayani, 2018). The last component of needs analysis is means analysis. According to Dudley-Evans \& St John (quoted by Rahman, 2015, p. 27), means analysis is an acknowledgment that works well in one situation but may not work in another. For example, a hotel staff around the world may share some similar language needs but the ways they learn or how they apply the language are not the same. Through doing means analysis, the course designer would only design the materials and activities directed and suitable for the target learners. All these components of needs are essential to be considered by the course designers, especially those in the tertiary level of education.

In the English Education Department of Universitas Tanjungpura, ESP subjects are taught. It aims to prepare the students to get other jobs than the English teachers as formulated in the graduate profiles. There are four ESP subjects taught, and English for Tourism (EFT) is one of them. The EFT course taught in the fourth semester provides the students with specific materials and skills of English used in the tourism industry, such as hospitality and tour management and agency. The purpose of giving EFT course to English education students is primarily to equip them with the specific English skills and knowledge about tourism industry, especially for those who are less interested in becoming teachers and are more interested in this industry. As observed by the researchers for the last two years or two batches, students have not only enrolled to English study 
program to be teachers, but they also have other targets of careers, such as becoming tour guides, travel agencies owners, and hotel employees. Therefore, it is expected that the study program could help and equip the students with the skills and knowledge to pursue their dreams. Therefore, ESP courses, in this case is EFT course, are arranged to be taught to students to meet their needs.

In the general curriculum of ESP, the position of EFT is located precisely under the English for Professional Purposes (EPP) indicating that English is expected to be used in tourism areas by professionals. Figure 1 below is the depiction of EFT position in ESP suggested by Puspitasari (2018).

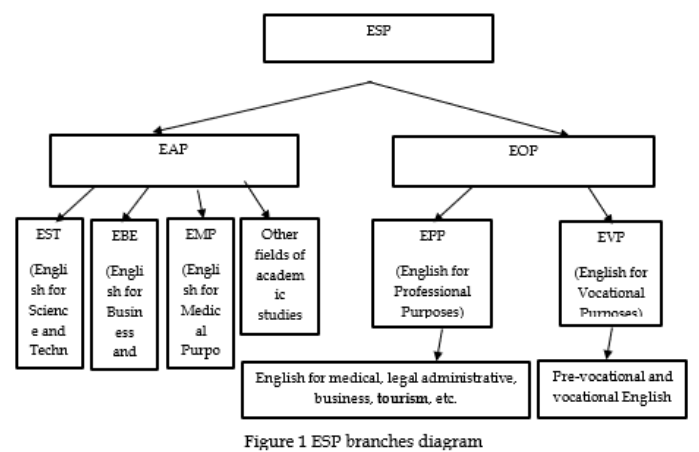

The procurement of this course is to meet the needs of the tourism sectors in West Kalimantan, which has been developing and embracing the global market. Nowadays, the number of tourist destinations in West Kalimantan keeps growing, that more attractions are opened, such as forests, beaches, hills, lakes, and waterfalls. This phenomenon has led the officials' attention that in 2019 the government agreed to focus on developing the tourism sector, as stated in Provincial Regulation No.2 of 2019 about the Regional Medium-Term Development Plan. In this policy, the government aims to attract more international tourists to West Kalimantan to increase the economy and regional income. When this program is executed, the stakeholders, including hotels and tourism agencies, would need to recruit more competent employees in English.
Knowing this great opportunity, the English Education Department, through the EFT course, prepares the students to participate professionally.

EFT course, meticulously, as an ESP subject, has to provide relevant materials and skills that can meet at least two main demands: target situations and the student's needs, as suggested by Basturkmen (2010). Every year, students who enroll for the EFT course are different; and in a year, the stakeholders of the tourism and hospitality sectors which included hotels and travel agencies (Pitana cited in Puspitasari, 2018) are developing. Consequently, there has to be needs analysis conducted at least annually to meet the current needs of both EFT students and the stakeholders. Stakeholders needs analysis was considered important for EFT course because the results would become a benchmark of students' success (Puspitasari, 2018). In the light of this matter, the researchers of this study conducted a needs analysis research focusing on investigating the needs of EFT course students and the stakeholders involving hotels and tour and travel agencies in Pontianak.

Researches on needs analysis on English used in the tourism industry are plenty (e.g., Anam \& Rachmadian, 2020; Asrifan et al., 2020; Dayu \& Haura, 2016; Oktarin et al., 2019; Prachanant, 2012; Puspitasari, 2018; Ratmanida et al., 2020; Salisna et al., 2019; Yotimart \& Wongchai, 2014). The results of these studies varied, yet they emphasized the usefulness of the needs analysis itself. Amongst these researches, in Indonesia specifically, studies conducted by Anam \& Rachmadian (2020), Dayu and Haura (2016), Puspitasari (2018), and Ratmanida et al. (2020) were closely related to the researchers' in terms of the level of education they targeted. The results inspired the researchers to have a similar study. However, the participants of those studies were limited to the 
particular party; for example, Puspitasari's work gathered the needs from stakeholders only while Dayu and Haura's work analyzed the needs from the students' aspect. Differently, this research took two parties for the participants: the EFT class and the tourism stakeholders. By doing so, the researchers had richer data from various viewpoints. As a result, the course designers could develop better materials for the EFT course. Hence, this descriptive quantitative study addressed two research questions: (1) What are the needs of stakeholders in terms of English skills competence and tourism topics? (2) What are the needs of students in terms of English skills competence, topics, and classroom activities? The researchers believed that the needs examined from this study would be helpful to develop more specific, directed, and relevant EFT courses for students.

\section{Method}

This study employed a descriptive quantitative design. Descriptive quantitative is a part of quantitative methodology categorized as a nonexperimental study. According to Gay et al. (2012), descriptive research is used to collect the opinions of targeted parties about the research issue that are analyzed through statistical analysis. It is an observational research study focusing on particular aspect of behavior or thoughts that can be quantified through measurement (Leedy \& Ormrod, 2015).

\section{Participants}

The participants were stakeholders of the tourism industry involving ten hotels, five travel agents in Pontianak, and 86 second-semester students of the English Education Department of FKIP Universitas Tanjungpura Pontianak.

\section{Instruments}

The research instrument for collecting the data was a close-ended questionnaire. The questionnaires were distributed to tourism stakeholders and English Education Department students with different content. The English students' questionnaire covered 3 information: preferred EFT topics (in the form of Yes/No), classroom activities and tasks (in the form of free selection), and English language skills (in the form of Likert Scale of 3 ratings: most needed, needed, and less needed).

Meanwhile, the stakeholders' questionnaire was divided into 2 parts: Part 1 the need of English language skill (in the form of Likert Scale of 3 ratings: most needed, needed, less needed), and Part 2 the preferred EFT topics (in the form of $\mathrm{Yes} / \mathrm{No}$ ). The stakeholder's questionnaire statements were adapted from Puspitasari (2018), Ratmanida et al. (2020), and Salisna et al. (2019).

\section{Data Analysis Procedures}

The data from questionnaire responses were tabulated and analyzed using percentage formula adopted from Ratmanida et al. (2020) as presented below.

Formula 1: Percentage Calculation

$$
\mathrm{P}=\mathrm{F} \text { X } 100 \% \mathrm{~N}
$$

$\mathrm{P}=$ the percentage of response

$\mathrm{F}=$ frequenc

$\mathrm{N}=$ total number of respondents

In details, the questionnaire analyses of the needs of English language skill were calculated using the percentage formula above, and the results were presented in the tables. Meanwhile, the questionnaire analyses of EFT topics and classroom activities were calculated using the percentage formula, and the results were categorized using the mean range to determine the level of the need adopted from Ratmanida et al. (2020) as follows:

Table 1. The mean range to determine the level of the need

\begin{tabular}{|c|c|c|}
\hline Scale & Mean range & Need level \\
\hline 4 & $76-100$ & Most needed \\
\hline 3 & $51-75$ & Needed \\
\hline 2 & $26-50$ & Less needed \\
\hline 1 & $0-25$ & Not needed \\
\hline
\end{tabular}

\section{Results and Discussion}


This section displays the results of questionnaire analysis gathered from the English Education Department students and tourism stakeholders (10 hotels and 5 travel agents).

\section{Questionnaire results from hotels (stakeholder)}

Part 1: The need of English language skill

Table 2. Hotel Stakeholders' responses for Part 1

\begin{tabular}{cccc}
\hline Skill & $\begin{array}{c}\text { Most } \\
\text { Needed }\end{array}$ & Needed & $\begin{array}{c}\text { Less } \\
\text { Needed }\end{array}$ \\
\hline Speaking & $100 \%$ & $0 \%$ & $0 \%$ \\
Writing & $70 \%$ & $30 \%$ & $0 \%$ \\
Reading & $50 \%$ & $40 \%$ & $10 \%$ \\
Listening & $40 \%$ & $40 \%$ & $20 \%$ \\
\hline
\end{tabular}

From Table 2, it can be learned that the responses from hotel stakeholders varied. Out of 4 skills responded, all respondents agreed that speaking skill is the most needed skill in the hospitality (hotel) industry with $100 \%$. The second most needed skill, according to hotel stakeholders, is writing that 7 out of 10 respondents responded the skill as most needed one with the percentage of $70 \%$. Then, the third is reading skill which is responded by 5 out 5 respondents with the percentage of $50 \%$. The least most needed skill to be responded is listening in which only 4 hotel stakeholders responded it with the percentage of $40 \%$. Meanwhile, for the needed category, the hotel stakeholders responded that listening and reading skills were needed in this industry with $40 \%$. These results indicated clearly that speaking and writing would be the most used skills in the hotel industry.

Part 2: Topics of EFT

Table 3. Hotel Stakeholders' responses for Part 2

\begin{tabular}{lcc}
\hline \multicolumn{1}{c}{ Topics } & Response & \% \\
\hline $\begin{array}{l}\text { Hotel services } \\
\text { and facilities }\end{array}$ & 10 & $100 \%$ \\
$\begin{array}{l}\text { Hotel } \\
\text { reservation, }\end{array}$ & 10 & $100 \%$ \\
\hline
\end{tabular}

\begin{tabular}{lll}
\hline $\begin{array}{l}\text { check-in, and } \\
\text { check-out }\end{array}$ & & \\
$\begin{array}{l}\text { Terminologies in } \\
\text { hotel }\end{array}$ & 10 & $100 \%$ \\
$\begin{array}{l}\text { Handling } \\
\text { complaint }\end{array}$ & 10 & $100 \%$ \\
$\begin{array}{l}\text { Presentation and } \\
\text { marketing }\end{array}$ & 10 & $100 \%$ \\
$\begin{array}{l}\text { Describing } \\
\text { places or rooms }\end{array}$ & 10 & $100 \%$ \\
$\begin{array}{l}\text { in hotels } \\
\text { Answering }\end{array}$ & 10 & $100 \%$ \\
$\begin{array}{l}\text { questions and } \\
\text { solving problems }\end{array}$ & & \\
$\begin{array}{l}\text { Phone class } \\
\text { Correspondents }\end{array}$ & 9 & $90 \%$ \\
$\begin{array}{l}\text { Giving and } \\
\text { clarifying }\end{array}$ & 8 & $80 \%$ \\
information & & $80 \%$ \\
$\begin{array}{l}\text { Describing jobs } \\
\text { duties) of } \\
\text { divisions in hotel }\end{array}$ & 8 & $80 \%$ \\
$\begin{array}{l}\text { Types of } \\
\text { accommodation } \\
\text { and }\end{array}$ & & \\
transportations & 6 & $60 \%$ \\
$\begin{array}{l}\text { Giving directions } \\
\text { Event planner } \\
\text { Kitchen }\end{array}$ & 5 & $50 \%$ \\
\hline
\end{tabular}

From Table 3 above, it can be seen that there were seven topics about hotel industry responded by $100 \%$. They include (1) hotel services and facilities; (2) hotel reservation, check-in, and check-out, (3) terminologies in a hotel, (4) handling complaints, (5) presentation and marketing, (6) describing places or rooms in a hotel, and (7) answering questions and solving problems. The results indicated that hotel employees had to be skillful in these topic areas. Meanwhile, phone calls, correspondence, giving and clarifying information, and describing jobs of divisions in the hotel are responded to as the second-highest demanded skills to acquire in the hotel industry with $90 \%$ and $80 \%$ respectively, yet still categorized as "much needed". On the other hand, according to the participants, topics about kitchen, event planner, and giving directions were the least demanded ones responded merely 
$30 \%, 40 \%$, and $50 \%$ categorized as "less needed".

\section{Questionnaire results from travel agent (stakeholder)}

Part 1: The need of English language skill

Table 4. The travel agents' responses for

\begin{tabular}{cccc}
\multicolumn{4}{c}{ Part 1 } \\
\hline Skill & $\begin{array}{c}\text { Most } \\
\text { Needed }\end{array}$ & Needed & $\begin{array}{c}\text { Less } \\
\text { Needed }\end{array}$ \\
\hline Speaking & $100 \%$ & $0 \%$ & $0 \%$ \\
Writing & $60 \%$ & $40 \%$ & $0 \%$ \\
Listening & $50 \%$ & $60 \%$ & $0 \%$ \\
Reading & $40 \%$ & $60 \%$ & $0 \%$ \\
\hline
\end{tabular}

From Table 4 above, it can be indicated that speaking is the most needed skill according to the travel agents with the percentage of $100 \% \ldots$ followed by writing $50 \%$, listening $50 \%$, and reading $40 \%$. On the other hand, listening and reading were needed skills with the percentage of $60 \%$ followed by writing with the percentage of $40 \%$. According to them, all English skills were needed for travel agents that none of them responded to less needed for the skills.

Part 2: Topic of EFT

Table 5. Travel agents' responses for Part 2

\begin{tabular}{lcc}
\hline \multicolumn{1}{c}{ Topic } & Response & \% \\
\hline $\begin{array}{l}\text { Flight } \\
\text { reservation }\end{array}$ & 5 & $100 \%$ \\
$\begin{array}{l}\text { Hotel } \\
\text { reservation, } \\
\text { check-in, and } \\
\text { check-out }\end{array}$ & 5 & $100 \%$ \\
$\begin{array}{l}\text { Terminologies in } \\
\text { travel agency }\end{array}$ & 5 & $100 \%$ \\
$\begin{array}{l}\text { Culinary } \\
\text { (describing }\end{array}$ & 4 & $80 \%$ \\
$\begin{array}{l}\text { suggesting } \\
\text { foods) }\end{array}$ & & \\
$\begin{array}{l}\text { Tour package } \\
\text { Tourist } \\
\text { attractions }\end{array}$ & 5 & $100 \%$ \\
$\begin{array}{l}\text { Itinerary } \\
\text { schedule }\end{array}$ & 5 & $100 \%$ \\
$\begin{array}{l}\text { Handling } \\
\text { complaint }\end{array}$ & 5 & $100 \%$ \\
$\begin{array}{l}\text { Phone calls } \\
\text { Types } \\
\text { accommodation }\end{array}$ & 5 & $100 \%$ \\
\hline
\end{tabular}

\begin{tabular}{lcc}
\hline and & & \\
transportation & & \\
$\begin{array}{l}\text { Correspondents } \\
\text { Event planner }\end{array}$ & 4 & $80 \%$ \\
$\begin{array}{l}\text { Presentation and } \\
\text { marketing }\end{array}$ & 5 & $100 \%$ \\
$\begin{array}{l}\text { Giving } \\
\text { Directions }\end{array}$ & 5 & $100 \%$ \\
$\begin{array}{l}\text { Giving } \\
\text { clarifying } \\
\text { information }\end{array}$ & 5 & $100 \%$ \\
$\begin{array}{l}\text { Describing } \\
\text { places }\end{array}$ & & \\
$\begin{array}{l}\text { Answering } \\
\text { questions and } \\
\text { solving problems }\end{array}$ & 5 & $100 \%$ \\
Tour guiding & 5 & $100 \%$ \\
\hline
\end{tabular}

Table 5 above revealed that 14 out of 18 EFT topics were responded to by $100 \%$. It means the topics proposed were applicable or relevant to the travel agent industry. From the analysis result, it can be learned that there was 1 topic about event planner responded very low (40\%) categorized as "less needed". For the rest, three topics about culinary, accommodation, transportation, and correspondents were responded relatively high (80\%), implying that these topics were used or considered necessary in the travel agent industry.

\section{Questionnaire Results from students}

Part 1: The need of English language skill in EFT subject

Table 6. Students' responses for Part 1

\begin{tabular}{cccc}
\hline Skill & $\begin{array}{c}\text { Most } \\
\text { Needed }\end{array}$ & Needed & $\begin{array}{c}\text { Less } \\
\text { Needed }\end{array}$ \\
\hline Listening & $67.4 \%$ & $19.7 \%$ & $12.8 \%$ \\
Speaking & $91.8 \%$ & $10.4 \%$ & $0 \%$ \\
Reading & $73.2 \%$ & $16.2 \%$ & $10.4 \%$ \\
Writing & $82.6 \%$ & $12.8 \%$ & $4.6 \%$ \\
\hline
\end{tabular}

Table 6 showed us the results of English language skills need analysis responded by the English Education Department students. From the table, it can be learned that speaking is taken as the most needed skill by students with the percentage of $91.8 \%$ followed by writing $82.6 \%$, reading $73.2 \%$, and listening $67.4 \%$. Meanwhile, the less needed skill responded is listening skill with the 
percentage of $12.8 \%$. These results indicated that students were aware of the importance of acquiring speaking skill in tourism industry.

Part 2: The preferred EFT topics (22 topics)

Table 7: Students' responses for Part 2

\begin{tabular}{|c|c|c|}
\hline Topic & Response & $\%$ \\
\hline $\begin{array}{l}\text { Tourist } \\
\text { attractions }\end{array}$ & 86 & $100.0 \%$ \\
\hline $\begin{array}{l}\text { Handling } \\
\text { complaint }\end{array}$ & 84 & $97.7 \%$ \\
\hline $\begin{array}{l}\text { Hotel } \\
\text { reservation, } \\
\text { check-in, and } \\
\text { check-out }\end{array}$ & 83 & $96.5 \%$ \\
\hline Tour guiding & 83 & $96.5 \%$ \\
\hline Correspondents & 82 & $95.3 \%$ \\
\hline $\begin{array}{l}\text { Itinerary and } \\
\text { schedule }\end{array}$ & 80 & $93.0 \%$ \\
\hline $\begin{array}{l}\text { Answering } \\
\text { questions and } \\
\text { solving } \\
\text { problems }\end{array}$ & 80 & $93.0 \%$ \\
\hline $\begin{array}{l}\text { Terminologies } \\
\text { in hotel }\end{array}$ & 80 & $93.0 \%$ \\
\hline $\begin{array}{l}\text { Hotel services } \\
\text { and facilities }\end{array}$ & 79 & $91.9 \%$ \\
\hline $\begin{array}{l}\text { Flight } \\
\text { reservation }\end{array}$ & 77 & $89.5 \%$ \\
\hline $\begin{array}{l}\text { Presentation } \\
\text { and marketing }\end{array}$ & 77 & $89.5 \%$ \\
\hline $\begin{array}{l}\text { Describing jobs } \\
\text { (duties) of } \\
\text { divisions in } \\
\text { hotel }\end{array}$ & 75 & $87.2 \%$ \\
\hline $\begin{array}{l}\text { Giving and } \\
\text { clarifying } \\
\text { information }\end{array}$ & 74 & $86.0 \%$ \\
\hline Phone calls & 73 & $84.9 \%$ \\
\hline $\begin{array}{l}\text { Culinary } \\
\text { (describing and } \\
\text { suggesting } \\
\text { foods) }\end{array}$ & 71 & $82.6 \%$ \\
\hline $\begin{array}{l}\text { Giving } \\
\text { Directions }\end{array}$ & 70 & $81.4 \%$ \\
\hline $\begin{array}{l}\text { Describing } \\
\text { places }\end{array}$ & 69 & $80.2 \%$ \\
\hline $\begin{array}{l}\text { Types of } \\
\text { accommodation }\end{array}$ & 66 & $76.7 \%$ \\
\hline
\end{tabular}

and
transportation
Terminologies
in travel agency
Event planner
Kitchen
Tour package 59
Table 7 showed the results of students"
preference on EFT topics. From the data,
it can be seen that there are only 3 topics
are categorized as "needed" based on the
analysis results of students' responses.
They are terminologies in travel agency
(75.6\%), event planner (68.6\%), and
kitchen (68.6\%). The rest of the topics (19
topics precisely) were categorized as
"much needed". In details, out of 19 most
needed topics, there are 9 topics got the
highest response from the students with
the range of percentage 91.9\% - 100\%.
They include (1) hotel reservation, check-
in, and check-out (96.5\%); (2) tourist
attractions (100\%), (3) itinerary and
schedule; (4) handling complaints
(97.7\%); (5) correspondents (95.3\%); (6)
answering questions and solving
problems (93\%); (7) tour guiding
(96.5\%); (8) hotel services and facilities
(91.9\%); and (9) terminologies in hotel
(93\%).

Part 3: The preferred classroom activities and tasks

Table 8. Types of classroom activities

\begin{tabular}{ccc}
\hline $\begin{array}{c}\text { Types of } \\
\text { classroom } \\
\text { activities }\end{array}$ & Responses & Percentage \\
\hline $\begin{array}{c}\text { Small group } \\
\text { work }\end{array}$ & 79 & $91.7 \%$ \\
$\begin{array}{c}\text { Large group } \\
\text { work }\end{array}$ & 66 & $76.7 \%$ \\
Individual & 53 & $61.6 \%$ \\
pair work & 41 & $47.6 \%$ \\
\hline
\end{tabular}

Table 8 displays the data of preferred types of classroom activities responded by the students. The results indicated that the most needed or preferred classroom activity is the small group work (91.7\%), and the second most needed activity is the large group work (76.7). According to the students, the less needed or less preferred 
classroom activity is the pair work $(47.6 \%)$.

Table 9. Types of tasks on each skill

\begin{tabular}{clcc}
\hline Skill & Task types & Response & \% \\
\hline Liste & Matching & 80 & $93.0 \%$ \\
-ning & $\begin{array}{l}\text { Multiple } \\
\text { choice }\end{array}$ & 76 & $88.4 \%$ \\
& Completing & 75 & $87.2 \%$ \\
& $\begin{array}{l}\text { Short } \\
\text { answering }\end{array}$ & 75 & $87.2 \%$ \\
& questions & & \\
Read & Multiple & 86 & $100.0 \%$ \\
-ing & choice & & \\
& Short & 83 & $96.5 \%$ \\
& Answering & & \\
& questions & & \\
& Summary & 68 & $79.1 \%$ \\
& Matching & 55 & $64.0 \%$ \\
& Completing & 42 & $48.8 \%$ \\
Spea- & Role play & 84 & $97.7 \%$ \\
king & Presentation & 80 & $93.0 \%$ \\
& Talks or & 71 & $82.6 \%$ \\
& dialogues & & \\
& One-on-one & 33 & $38.4 \%$ \\
speaking & & \\
Writ- & Creative & 68 & $79.1 \%$ \\
ing & writing & & \\
& Composition & & \\
& Essay & 59 & $68.6 \%$ \\
& Report & 52 & $60.5 \%$ \\
& Rewriting & 43 & $50.0 \%$ \\
\hline
\end{tabular}

Table 9 displays the results of students' responses towards the preferred types of tasks on each English skill to be done in the classroom. From the response, it can be seen that on each skill the students preferred or needed different tasks to have. In listening skill, for example, all the tasks types were categorized as most needed based on the response; however, the highest response goes to matching task with 80 responses $(93 \%)$ out of the other three responses. Then, in reading skill, the students preferred to have multiple choice $(100 \%)$ and short answering questions (96.5\%) the most. Meanwhile, in speaking skill, the students preferred to have the role play $(97.7 \%)$ and presentation (93\%) the most. Finally, in writing skill, the highest response goes to creative writing composition $(79.1 \%)$ which is also categorized as the most needed skill.

From the data above, it can be seen that the needs of the tourism stakeholders and students were somewhat similar. There are two main points revealed. First, in terms of the most demanded or needed skills, all participants chose the speaking gift as the first and writing as the second most needed skill. It is in line with the results from previous studies, which also figured out that speaking and writing were the most needed skills in tourism (Puspitasari, 2018; Ratmanida et al., 2020). It is highly possible because tourism sectors deal with people requiring active skills more than the passive ones (Dayu \& Haura, 2016; Prachanant, 2012; Yotimart \& Wongchai, 2014). People who work for tourism stakeholders (either in hotels or travel agencies) would be interacting with the tourists directly, through phones, emails, or text messaging. Thus, speaking and writing become the most important skills to acquire. Then, following how the works are done, being hospitable is needed for which hospitality is the primary part of tourism (Dayu \& Haura, 2016; Kardijan \& Emzir, 2017; Prachanant, 2012; Puspitasari, 2018; Ratmanida et al., 2020; Yotimart \& Wongchai, 2014).

Second, based on the results of EFT topic analyses, expressions such as handling complaints, giving and clarifying information, describing places, phone calls, and answering questions and solving problems received the highest responses. On the contrary, different responses were revealed by Ratmanida et al. (2020). Based on the results of their study, the expressions mentioned above were not significantly needed by the stakeholders for which the mean range was in the "less needed" category. In comparison, in her study, Puspitasari (2018) mentioned that the stakeholders highly demanded the topics related to complaints, phone calls, and problem 
solving. These various responses happened to the other issues, as well. For example, in Puspitasari's work (2018), topics related to hotelier (such as hotel reservation, facilities, check-in, and check-out) were responded higher than the one revealed by Ratmanida et al. (2020). In contrast, the researchers' study showed that those topics were demanded or needed by students and tourism stakeholders. It implies that different area or city where studies on the needs of the tourism industry are conducted might show different results following the needs or characteristics of the stakeholders, places, and other related factors?. Therefore, it is always essential for the ESP course designer (in this case, is EFT course) to always have need analysis in the first place before designing materials, as suggested by Basturkmen (2010).

\section{Conclusion}

A need analysis study has always been important to do before designing an ESP course material. Specifically, in English for tourism, the opinions from tourism stakeholders as the target users are essential. That is why, to design relevant, directed, and valuable materials for EFT students, an analysis study to find out the needs of tourism stakeholders has to be done. Considering its importance, the researchers had conducted a needs analysis of the ten hotels, five travel agents, and 86 students who would enroll for the EFT class as the initial phase to design the EFT course material. In a broader sense, the researchers expects that the study could motivate other ESP researchers or course designers to conduct similar investigations to the other ESP courses so that the students could get the most relevant materials and skills related to the purposes of the course.

\section{References}

Anam, M. M., \& Rachmadian, A. (2020). Need analysis of English language usage for Tourism university students. EnJourMe (English Journal of Merdeka): Culture, Language, and Teaching of English, 5(2), 178-187. https://doi.org/10.26905/enjourme.v $5 \mathrm{i} 2.5105$

Asrifan, A., Vargheese, K. J., Syamsu, T., \& Amir, M. (2020). Esp Course Design: the Need Analysis on Tourism Department in Indonesia Vocational High Schools. Journal of Advanced English Studies, 3(2), 6977.

Basturkmen, H. (2010). Developing Courses in English for Specific Purposes. Palgrave and Macmillan.

Dayu, A. T., \& Haura, R. (2016). Designing ESP Materials of English Tourism Subject at English Education and Training Program of Uniska Banjarmasin. The 63rd TEFLIN International Conference 2016, 10-16.

Flowerdew, L. (2013). Needs Analysis and Curriculum Development in ESP. In B. Paltridge \& S. Starfield (Eds.), The Handbook of English for Specific Purposes (pp. 1-570). John Wiley \& Sons, Inc.

Gay, L. R., Mills, G. E., \& Airasian, P. W. (2012). Educational research; competencies for analysis and applications. Pearson Education, Inc.

Kardijan, D., \& Emzir, Z. R. (2017). Target situation analysis in implementation of English for hospitality specific purposes program. International Journal of English and Education, 1(January). http://www.ijee.org/yahoo_site_ad min/assets/docs/3.5125139.pdf

Lee, C.-L. (2016). Principles and Practices of ESP Course Design-A Case Study of. International Journal of Learning, Teaching and Educational Research, 15(2), 94105.

Leedy, P. D., \& Ormrod, J. E. (2015). 
Practical research: planning and design (11th ed.). Pearson Education Limited.

Oktarin, R., . S., \& Harahap, A. (2019). Needs Analysis of Esp for Tourism Study Program At Smkn 7 (Senior Vocational School) Kota Bengkulu. Journal of English Education and Teaching, 3(1), 14-28. https://doi.org/10.33369/jeet.3.1.1428

Paltridge, B., \& Starfield, S. (2013). The handbook of English for specific purposes (B. Paltridge \& S. Starfield (eds.)). Wiley-Blackwell. https://doi.org/10.1002/9781118339 855.ch16

Prachanant, N. (2012). Needs analysis on English Language use in tourism industry. Procedia - Social and Behavioral Sciences, 66, 117-125. https://doi.org/10.1016/j.sbspro.201 2.11.253

Puspitasari, I. (2018). Developing English for Tourism Materials Trough Stakeholders' Needs Analysis. English Review: Journal of English Education, 7(1), 147. https://doi.org/10.25134/erjee.v7i1. 1534

Rahman, M. (2015). English for Specific Purposes (ESP): a holistic review. Universal Journal of Educational Research, 3(1), 24-31. https://doi.org/10.13189/ujer.2015.0 30104

Ratmanida, Fatimah, S., Al-Hafizh, M., \& Chair, I. M. (2020). Need analysis on English for Hotel at the Faculty of Tourism and Hospitality at Universitas Negeri Padang. Advances in Social Science, Education and Humanities Research, 463, 48-53. https://doi.org/10.2991/assehr.k.200 819.010

Salisna, R., Harahap, A., \& Sofyan, D. (2019). Need Analysis of English for Tour and Travel Department of Vocational High School in
Bengkulu City. JOALL (Journal of Applied Linguistics \& Literature), 4(1), 1-12. https://doi.org/10.33369/joall.v4i1.6 303

Songhori, M. H. (2008). Introduction to Needs Analysis. English for Specific Purposes World, 7(4), 1-25.

Yotimart, D., \& Wongchai, A. (2014). A language needs analysis research of tourism personnel at Muang Tam Sanctuary for tourism English communication innovation. Proceedings of the International Conference on Education, Psychology, and Social Sciences Conference (ICEPs 2014), August 2014, 1-16.

Yundayani, A. (2018). Present situation analysis: atudents' early characteristics in writing for Academic Purposes. English Review: Journal of English Education, $\quad 6(2), \quad 119$. https://doi.org/10.25134/erjee.v6i2. 1262 